\title{
Corrigenda
}

\section{After shrinkage apoptotic cells expose internal membrane-derived epitopes on their plasma membranes}

\author{
S Franz, K Herrmann, BG Fürnrohr, A Sheriff, B Frey, US Gaipl, RE Voll, JR Kalden, H-M Jäck and M Herrmann
}

Cell Death and Differentiation (2008) 15, 805; doi:10.1038/sj.cdd.4402308

Correction to: Cell Death and Differentiation (2007) 14, 733-742;

The author name BG Fürnrohr was published incorrectly in the doi:10.1038/sj.cdd.4402066. above.

\section{Turn me on: regulating HIF transcriptional activity}

\author{
K Lisy and DJ Peet \\ Cell Death and Differentiation (2008) 15, 805; doi:10.1038/cdd.2008.27
}

Correction to: Cell Death and Differentiation: doi:10.1038/

sj.cdd.4402315; advance online publication, 18 January 2008

In this article published online and in this issue, an error has been identified in this review, in the description of the findings of reference 55 . The correct text should be:

Additionally, it has been reported that MAPK-mediated phosphorylation of serine residues 641 and 643 within the ID of HIF- $1 \alpha$ promotes activity by preventing CRM1-dependent nuclear export of the subunit. ${ }^{55}$

The authors would like to apologise for this error. 